\title{
Improving Use Efficiency of Inputs by Drip Irrigation in Bt Cotton
}

\author{
Harphool Meena ${ }^{1}$, K.C. Nagar ${ }^{2}$, B.L. Kumhar ${ }^{1}$ and Bachchu Singh ${ }^{1}$ \\ ${ }^{1}$ AICRP on Irrigation Water Management, Agricultural Research Station, Ummedganj Farm, \\ Agriculture University, Kota-324001, Rajasthan, India \\ ${ }^{2}$ Krishi Vigyan Kendra, Bhilwara, Rajasthan, India
}

\begin{tabular}{|l|}
\hline Ke y w or d s \\
$\begin{array}{l}\text { Drip irrigation, } \mathrm{Bt} \\
\text { cotton, nitrogen and } \\
\text { seed cotton yield }\end{array}$ \\
\hline Article Info \\
\hline $\begin{array}{l}\text { Accepted: } \\
\text { 28 December } 2017 \\
\text { Available Online: } \\
10 \text { March } 2018\end{array}$ \\
\hline
\end{tabular}

A B S T R A C T

An experiment was conducted during two consecutive years of kharif 2012 and 2013 at Agricultural Research Station, Banswara to find out the suitable drip irrigation regimes and optimum nitrogen dose for Bt cotton. The experiment was laid-out in split plot design with four replications having twelve treatment combinations. Results revealed that, the application of irrigation at 0.6 ET gave significantly higher seed cotton yield (1989 kg/ha) as compared to irrigation regime of $1.0 \mathrm{ET}$ and surface irrigation (control),but it was found at par with application of irrigation at $0.8 \mathrm{ET}(1905 \mathrm{~kg} / \mathrm{ha})$. Increasing the seed cotton yield of Bt cotton with increasing of nitrogen levels from 50\% RDN \& K to $100 \%$ RDN \& K. The maximum seed cotton yield (2068 kg/ha) was recorded under application of $100 \%$ RDN \& K over application of $75 \%$ and $50 \%$ RDN \& K (1673and $1448 \mathrm{~kg} / \mathrm{ha})$, respectively in the pooled analysis. Application of irrigation regime $0.6 \mathrm{ET}$ and $0.8 \mathrm{ET}$ were recorded higher net return (Rs.48598/- and 46458/- ha ${ }^{-1}$ ) and B: C ratio (2.31 and 2.30) over irrigation regime 1.0 ET and surface method (control). Significantly higher net return (Rs. 50380/- ha $^{-1}$ ) and B: C ratio (2.29) was recorded under application of $100 \%$ RDN\&K over $75 \%$ and $50 \%$ RDN\&K net return (Rs. 37538/- and 30680/- ha $^{-1}$ ) and B: C ratio (1.79 and $1.53)$, respectively in the pooled analysis.

\section{Introduction}

Drip irrigation method (DIM) is one of the technical measures introduced about two decades back to increase the water use efficiency in Indian agriculture. Under this method, water is delivered directly to the root zone of the crops using pipe network and emitters. This method is entirely different from the conventional method, where water is dispersed to the whole cropland, instead of dispensing exclusively to the crop. Since water is supplied at the required time and quantity using pipe network under DIM, excess irrigation as well as water losses occurring through conveyance and distribution is completely eliminated. Experiments based studies show that the water use efficiency can be achieved up to 100 per cent under DIM, whereas the same is possible only in the range of 35-40 per cent under flood method of irrigation (INCID, 1994; Sivanappan, 1994). Besides saving water, DIM is also capable of enhancing the productivity of crops that too at lower cost of cultivation (Narayanamoorthy, 2004 and Dhawan, 2002). DIM is relatively a 
new method of irrigation. It entails relatively large amount of fixed capital investment. Therefore, several studies have been carried out to find out the impact of DIM on different parameters of crop cultivation including its economic viability in different crops, using both experimental and field level data (INCID, 1994, Narayanamoorthy 2005). Studies especially carried out using field survey data on crops such as banana, grapes and sugarcane have shown that the DIM saves water by about 30-40 per cent, increases productivity about by 30-45 per cent and also lowers the cost of cultivation considerably as compared to the same crops cultivated under FIM with similar environment. Studies have also showed that the investment in drip irrigation is economically viable for farmers even without subsidy (Narayanamoorthy, 2003).

\section{Materials and Methods}

A field experiment was conducted during two consecutive years of kharif 2012 and 2013 at Agricultural Research Station, Banswara on "Improving use efficiency of inputs by drip irrigation in Bt cotton". The experiment was laid-out in split plot design with four replications having twelve treatment combinations i.e.(four irrigation regimes 0.6,0.8,1.0 ET and surface irrigation (control) and three nitrogen levels 100, 75 and 50\% RDN \& K).The experimental field was well prepared by two ploughing followed by harrowing \& cultivator and one planking for uniform levelling were performed for sowing of cotton. The soils of experimental field were (black cotton soil) clay loam texture and alkaline in reaction ( $\mathrm{pH} 7.9$ and 7.8). The soil was medium in available nitrogen (246 and $255 \mathrm{~kg} / \mathrm{ha}$ ) and phosphorus (48.85 and 50.56 $\mathrm{kg} / \mathrm{ha}$ ) and high in available potassium (323 and $325 \mathrm{~kg} / \mathrm{ha}$ ) during the years. The crop was sown in first week of June by dibbling of 2-3 seeds per hills and full dose of phosphorus and potash were applied before sowing, while nitrogen dose was given in two splits i.e. first half at the time of thinning and remaining half at flowering stage. All production and protection measures were applied as per package of the zone IV $b$.

\section{Results and Discussion}

\section{Growth}

It is evident from pooled data shows (Table 1) that the significantly influence plant growth of Bt cotton under application of irrigation regimes. The maximum plant height (117.15 $\mathrm{cm})$, monopodial branches plant ${ }^{-1}(1.34)$ and sympodial branches plant $^{-1}$ (23.65) were recorded under irrigation regime of $0.6 \mathrm{ET}$ over irrigation regime of $1.0 \mathrm{ET}$ and surface irrigation (control). However, it was found at par with application of irrigation regime at 0.8 ET plant height $(115.43 \mathrm{~cm})$, monopodial branches plant $^{-1}(1.30)$ and sympodial branches plant ${ }^{-1}$ (23.02). Increasing levels of nitrogen from $50 \%$ RDN\&K to $100 \%$ RDN\&K resulted in significantly increasing plant growth of $\mathrm{Bt}$ cotton. Application of $100 \%$ RDN\&K was recorded higher plant height $(120.64 \mathrm{~cm})$, monopodial branches plant $^{-1}$ (1.37) and sympodial branches plant ${ }^{-1}$ (22.87) over application of $75 \%$ and $50 \% \mathrm{RDN}$ \& $\mathrm{K}$ plant height $(112.58$ and $105.23 \mathrm{~cm})$, monopodial branches plant ${ }^{-1}$ (1.28 and 1.26) and sympodial branches plant ${ }^{-1}$ (20.47 and 19.25),respectively. These results are in accordance with the findings of Bhalearo et al., (2008), Jadhao et al., 1993 and Salikanop et al., (2010).

\section{Yield attributes}

Two years pooled data shows that (Table 2) the yield attributes of Bt cotton significantly influence with different irrigation regimes. Application of irrigation at 0.6 ET gave significantly higher bolls plant ${ }^{-1}$ (31.14) and boll weight (4.18) as compared to irrigation 
regime of 1.0 ET and surface irrigation (control), but it was found at par with application of irrigation regime at 0.8 ET bolls plant $^{-1}$ (28.65) and boll weight (4.09). Increasing the yield attributes of Bt cotton with increasing of nitrogen levels from 50\% RDN\&K to $100 \%$ RDN\&K. The maximum bolls plant ${ }^{-1}$ (27.88) and boll weight (4.08) were recorded under application of $100 \%$ RDN\&K over application of $75 \%$ and $50 \%$ RDN \& $\mathrm{K}^{\text {bolls }}$ plant $^{-1}$ (23.87 and20.75) and boll weight (3.88 and 3.64) during both the years as well as in pooled analysis. These results are in accordance with the findings of Jadhao et al., 1993, Bhalearo et al., (2008) and Salikanop et al., (2010).

\section{Seed cotton yield}

An examination of pooled data shows that the (Table 2) significantly influence of seed cotton yield of $\mathrm{Bt}$ cotton under application of different irrigation regimes. Application of irrigation at 0.6 ET gave significantly higher seed cotton yield $(1989 \mathrm{~kg} / \mathrm{ha})$ as compared to irrigation regime of 1.0 ET and surface irrigation (control). However, it was found at par with application of irrigation at $0.8 \mathrm{ET}$ seed cotton yield $(1905 \mathrm{~kg} / \mathrm{ha})$ in the pooled analysis. Increasing the seed cotton yield of $\mathrm{Bt}$ cotton with increasing of nitrogen levels from $50 \%$ RDN\&K to $100 \%$ RDN\&K. The maximum seed cotton yield $(2068 \mathrm{~kg} / \mathrm{ha})$ was recorded under application of $100 \%$ RDN\&K over application of $75 \%$ and $50 \%$ RDN \& K seed cotton yield (1673 and $1448 \mathrm{~kg} / \mathrm{ha}$ ), respectively. These results are in accordance with the findings of Bhalearo et al., (2008).

\section{Nitrogen content}

It is evident from pooled data shows that (Table 3) the nitrogen content in seed and straw of Bt cotton was not influence by different irrigation regimes. Increasing the nitrogen content in seed and straw of Bt cotton with increasing of nitrogen levels from 50\% RDN\&K to $100 \%$ RDN\&K. The significantly higher nitrogen content in seed (2.24 per cent) and straw (0.96 per cent) were recorded under application of $100 \%$ RDN\&K over application of $75 \% \mathrm{RDN} \& \mathrm{~K}$ seed ( 2.15 per cent) and straw ( 0.84 per cent) and $50 \%$ RDN \& K seed ( 2.14 per cent) and straw (0.81 per cent), respectively. These results are in accordance with the findings of Salikanop et al., (2010).

Table.1 Effect of irrigation regime and nitrogen levels on growth parameters of Bt cotton

\begin{tabular}{|c|c|c|c|c|c|c|c|c|c|}
\hline \multirow[t]{2}{*}{ Treatments } & \multicolumn{3}{|c|}{ Plant height (cm) } & \multicolumn{3}{|c|}{$\begin{array}{l}\text { Monopodial branches } \\
\text { plant }^{-1}\end{array}$} & \multicolumn{3}{|c|}{$\begin{array}{l}\text { Sympodial branches } \\
\text { plant }^{-1}\end{array}$} \\
\hline & 2012 & 2013 & Pooled & 2012 & 2013 & Pooled & 2012 & 2013 & Pooled \\
\hline \multicolumn{10}{|l|}{ Irrigation regimes } \\
\hline $0.6 \mathrm{ET}$ & 116.77 & 117.53 & 117.15 & 1.32 & 1.35 & 1.34 & 23.45 & 23.85 & 23.65 \\
\hline $0.8 \mathrm{ET}$ & 115.00 & 115.86 & 115.43 & 1.29 & 1.31 & 1.30 & 22.96 & 23.09 & 23.02 \\
\hline $1.0 \mathrm{ET}$ & 108.80 & 109.07 & 108.93 & 1.20 & 1.23 & 1.22 & 19.14 & 20.15 & 19.64 \\
\hline Surface irrigation (control) & 106.20 & 106.86 & 106.53 & 1.21 & 1.24 & 1.23 & 20.00 & 20.46 & 20.23 \\
\hline Sem \pm & 1.98 & 1.79 & 1.73 & 0.02 & 0.02 & 0.02 & 0.38 & 0.40 & 0.36 \\
\hline $\mathrm{CD}(\mathrm{P}=0.05)$ & 5.66 & 5.40 & 5.21 & 0.07 & 0.06 & 0.05 & 1.16 & 1.24 & 1.07 \\
\hline \multicolumn{10}{|l|}{ Nitrogen Levels } \\
\hline $100 \%$ RDN \&K & 120.26 & 121.02 & 120.64 & 1.36 & 1.38 & 1.37 & 22.70 & 23.05 & 22.87 \\
\hline $75 \%$ RDN \& K & 112.22 & 112.94 & 112.58 & 1.28 & 1.29 & 1.28 & 20.14 & 20.81 & 20.47 \\
\hline $50 \%$ RDN \& K & 105.20 & 105.27 & 105.23 & 1.25 & 1.26 & 1.26 & 19.01 & 19.50 & 19.25 \\
\hline Sem + & 2.01 & 1.84 & 1.77 & 0.02 & 0.02 & 0.02 & 0.37 & 0.35 & 0.33 \\
\hline $\mathrm{CD}(\mathrm{P}=0.05)$ & 5.95 & 5.56 & 5.31 & 0.06 & 0.07 & 0.05 & 1.12 & 1.07 & 0.99 \\
\hline
\end{tabular}


Int.J.Curr.Microbiol.App.Sci (2018) 7(3): 3632-3638

Table.2 Effect of irrigation regime and nitrogen levels on yield attributes and Seed cotton yield of Bt cotton

\begin{tabular}{|c|c|c|c|c|c|c|c|c|c|}
\hline \multirow[t]{2}{*}{ Treatments } & \multicolumn{3}{|c|}{ Bolls plant $^{-1}$} & \multicolumn{3}{|c|}{ Boll weight (g) } & \multicolumn{3}{|c|}{ Seed cotton yield (kg/ha) } \\
\hline & 2012 & 2013 & Pooled & 2012 & 2013 & Pooled & 2012 & 2013 & Pooled \\
\hline \multicolumn{10}{|l|}{ Irrigation regimes } \\
\hline 0.6 ET & 30.89 & 31.40 & 31.14 & 4.16 & 4.20 & 4.18 & 1967 & 2010 & 1989 \\
\hline $0.8 \mathrm{ET}$ & 28.30 & 29.00 & 28.65 & 4.08 & 4.11 & 4.09 & 1884 & 1925 & 1905 \\
\hline $1.0 \mathrm{ET}$ & 23.48 & 23.75 & 23.61 & 3.84 & 3.88 & 3.86 & 1503 & 1547 & 1525 \\
\hline $\begin{array}{l}\text { Surface irrigation } \\
\text { (control) }\end{array}$ & 23.80 & 23.96 & 23.88 & 3.90 & 3.93 & 3.91 & 1490 & 1532 & 1511 \\
\hline Sem \pm & 0.96 & 0.87 & 0.84 & 0.05 & 0.04 & 0.04 & 68 & 84 & 70 \\
\hline $\mathrm{CD}(\mathrm{P}=0.05)$ & 2.90 & 2.56 & 2.53 & 0.16 & 0.14 & 0.12 & 205 & 255 & 213 \\
\hline \multicolumn{10}{|l|}{ Nitrogen Levels } \\
\hline $100 \%$ RDN \&K & 27.44 & 28.32 & 27.88 & 4.04 & 4.12 & 4.08 & 2049 & 2087 & 2068 \\
\hline $75 \%$ RDN \& K & 23.72 & 24.01 & 23.87 & 3.87 & 3.90 & 3.88 & 1650 & 1695 & 1673 \\
\hline $50 \%$ RDN \& K & 20.50 & 21.00 & 20.75 & 3.60 & 3.68 & 3.64 & 1427 & 1469 & 1448 \\
\hline Sem \pm & 0.79 & 0.74 & 0.70 & 0.04 & 0.05 & 0.04 & 71 & 91 & 75 \\
\hline $\mathrm{CD}(\mathrm{P}=0.05)$ & 2.45 & 2.20 & 2.11 & 0.14 & 0.15 & 0.12 & 215 & 275 & 222 \\
\hline
\end{tabular}

Table.3 Effect of irrigation regime and nitrogen levels on nitrogen content and Uptake of Bt cotton

\begin{tabular}{|c|c|c|c|c|c|c|c|c|c|}
\hline \multirow[t]{3}{*}{ Treatments } & \multicolumn{6}{|c|}{ Nitrogen content $(\%)$} & \\
\hline & \multicolumn{3}{|c|}{ Seed } & \multicolumn{3}{|c|}{ Straw } & \multicolumn{3}{|c|}{ Seed } \\
\hline & 2012 & 2013 & Pooled & 2012 & 2013 & Pooled & 2012 & 2013 & Pooled \\
\hline \multicolumn{10}{|l|}{ Irrigation regimes } \\
\hline $0.6 \mathrm{ET}$ & 2.12 & 2.16 & 2.14 & 0.82 & 0.85 & 0.84 & 37.98 & 38.22 & 38.10 \\
\hline $0.8 \mathrm{ET}$ & 2.15 & 2.17 & 2.16 & 0.84 & 0.86 & 0.85 & 34.76 & 35.60 & 35.18 \\
\hline $1.0 \mathrm{ET}$ & 2.19 & 2.20 & 2.20 & 0.88 & 0.90 & 0.89 & 27.50 & 28.25 & 27.88 \\
\hline $\begin{array}{l}\text { Surface irrigation } \\
\text { (control) }\end{array}$ & 2.16 & 2.18 & 2.17 & 0.85 & 0.87 & 0.86 & 28.04 & 28.48 & 28.26 \\
\hline Sem \pm & 0.03 & 0.02 & 0.02 & 0.03 & 0.02 & 0.02 & 1.72 & 1.65 & 1.55 \\
\hline $\mathrm{CD}(\mathrm{P}=0.05)$ & NS & NS & NS & NS & NS & NS & 5.06 & 4.91 & 4.68 \\
\hline \multicolumn{10}{|l|}{ Nitrogen Levels } \\
\hline $100 \%$ RDN \&K & 2.23 & 2.25 & 2.24 & 0.95 & 0.96 & 0.96 & 35.39 & 35.67 & 35.53 \\
\hline $75 \%$ RDN \& K & 2.15 & 2.16 & 2.15 & 0.84 & 0.84 & 0.84 & 27.66 & 28.00 & 27.83 \\
\hline $50 \%$ RDN \& K & 2.13 & 2.15 & 2.14 & 0.80 & 0.82 & 0.81 & 23.32 & 23.64 & 23.48 \\
\hline Sem \pm & 0.03 & 0.03 & 0.02 & 0.03 & 0.03 & 0.02 & 2.07 & 1.95 & 1.85 \\
\hline $\mathrm{CD}(\mathrm{P}=0.05)$ & 0.07 & 0.08 & 0.06 & 0.10 & 0.09 & 0.08 & 6.20 & 5.81 & 5.54 \\
\hline
\end{tabular}


Int.J.Curr.Microbiol.App.Sci (2018) 7(3): 3632-3638

Table.4 Effect of irrigation regime and nitrogen levels on nitrogen uptake by plant of Bt cotton

\begin{tabular}{|c|c|c|c|c|c|c|c|c|c|}
\hline \multirow[t]{3}{*}{ Treatments } & \multicolumn{6}{|c|}{ Nitrogen uptake (kg/ha) } & \multirow{2}{*}{\multicolumn{3}{|c|}{$\begin{array}{l}\text { Nitrogen use efficiency } \\
\qquad\left(\mathrm{kg} \mathrm{kg}^{-1} \mathrm{~N}\right)\end{array}$}} \\
\hline & \multicolumn{3}{|c|}{ By straw } & \multicolumn{3}{|c|}{ Total } & & & \\
\hline & 2012 & 2013 & Pooled & 2012 & 2013 & Pooled & Seed & Straw & Pooled \\
\hline \multicolumn{10}{|l|}{ Irrigation regimes } \\
\hline $0.6 \mathrm{ET}$ & 59.02 & 60.45 & 59.73 & 38.10 & 59.73 & 97.83 & 23.28 & 23.37 & 23.33 \\
\hline $0.8 \mathrm{ET}$ & 54.63 & 55.87 & 55.25 & 35.18 & 55.25 & 90.43 & 22.08 & 22.15 & 22.12 \\
\hline $1.0 \mathrm{ET}$ & 43.70 & 44.34 & 44.02 & 27.88 & 44.02 & 71.90 & 19.11 & 19.31 & 19.21 \\
\hline $\begin{array}{l}\text { Surface irrigation } \\
\text { (control) }\end{array}$ & 44.01 & 44.98 & 44.50 & 28.26 & 44.50 & 72.76 & 19.68 & 19.85 & 19.76 \\
\hline Sem \pm & 2.40 & 2.12 & 2.08 & 2.14 & 2.98 & 2.36 & 0.52 & 0.47 & 0.46 \\
\hline $\mathrm{CD}(\mathrm{P}=0.05)$ & 7.18 & 6.40 & 6.24 & 6.50 & 8.94 & 8.05 & 1.50 & 1.45 & 1.37 \\
\hline \multicolumn{10}{|l|}{ Nitrogen Levels } \\
\hline $100 \%$ RDN \&K & 59.70 & 62.30 & 61.00 & 35.53 & 61.00 & 96.53 & 21.55 & 21.48 & 21.52 \\
\hline $75 \%$ RDN \& K & 50.06 & 51.47 & 50.77 & 27.83 & 50.77 & 78.60 & 20.23 & 20.29 & 20.26 \\
\hline $50 \%$ RDN \& K & 47.03 & 48.12 & 47.58 & 23.48 & 47.58 & 71.06 & 19.28 & 19.47 & 19.37 \\
\hline Sem \pm & 2.68 & 2.40 & 2.33 & 2.09 & 3.01 & 2.35 & 0.28 & 0.31 & 0.27 \\
\hline $\mathrm{CD}(\mathrm{P}=0.05)$ & 8.32 & 7.26 & 7.01 & 6.30 & 9.00 & 7.40 & 0.85 & 0.97 & 0.82 \\
\hline
\end{tabular}

Table.5 Effect of irrigation regime and nitrogen levels on nitrogen use efficiency and water use efficiency of Bt cotton

\begin{tabular}{|c|c|c|c|c|c|c|c|c|c|}
\hline \multirow[t]{2}{*}{ Treatments } & \multicolumn{3}{|c|}{ Water use efficiency (kg ha/cm) } & \multicolumn{3}{|c|}{ Net return (Rs./ha) } & \multicolumn{3}{|c|}{ B:C ratio } \\
\hline & 2012 & 2013 & Pooled & 2012 & 2013 & Pooled & Seed & Straw & Pooled \\
\hline \multicolumn{10}{|c|}{ Irrigation regimes } \\
\hline $0.6 \mathrm{ET}$ & 27.32 & 25.28 & 26.30 & 47845 & 49350 & 48598 & 2.28 & 2.35 & 2.31 \\
\hline $0.8 \mathrm{ET}$ & 26.17 & 24.21 & 25.19 & 45740 & 47175 & 46458 & 2.26 & 2.34 & 2.30 \\
\hline $1.0 \mathrm{ET}$ & 20.88 & 19.46 & 20.17 & 33005 & 34545 & 33775 & 1.68 & 1.76 & 1.72 \\
\hline $\begin{array}{l}\text { Surface irrigation } \\
\text { (control) }\end{array}$ & 20.69 & 19.27 & 19.98 & 32150 & 33620 & 32885 & 1.61 & 1.68 & 1.64 \\
\hline Sem \pm & 1.36 & 1.29 & 1.20 & 2954 & 3105 & 2788 & 0.15 & 0.14 & 0.13 \\
\hline $\mathrm{CD}(\mathrm{P}=0.05)$ & 4.10 & 3.94 & 3.67 & 8860 & 9218 & 8360 & 0.42 & 0.43 & 0.40 \\
\hline \multicolumn{10}{|c|}{ Nitrogen Levels } \\
\hline $100 \%$ RDN \&K & 28.46 & 26.25 & 27.35 & 49715 & 51045 & 50380 & 2.26 & 2.32 & 2.29 \\
\hline $75 \%$ RDN \& K & 22.92 & 21.32 & 22.12 & 36750 & 38325 & 37538 & 1.75 & 1.83 & 1.79 \\
\hline $50 \%$ RDN \& K & 19.82 & 18.48 & 19.15 & 29945 & 31415 & 30680 & 1.50 & 1.57 & 1.53 \\
\hline Sem \pm & 2.04 & 1.56 & 1.66 & 2400 & 2278 & 2152 & 0.11 & 0.09 & 0.09 \\
\hline $\mathrm{CD}(\mathrm{P}=0.05)$ & 6.09 & 4.60 & 4.91 & 7185 & 6745 & 6447 & 0.30 & 0.27 & 0.28 \\
\hline
\end{tabular}

Nitrogen uptake

Pooled data of two years shows that (Table 4) the nitrogen uptake by seed, straw and total of
Bt cotton were significantly influence by various irrigation regimes. Application of irrigation at $0.6 \mathrm{ET}$ and $0.8 \mathrm{ET}$ were found at par with each other in terms of nitrogen 
uptake by seed ( 38.10 and $35.18 \mathrm{~kg} / \mathrm{ha})$, straw $(59.73$ and $55.25 \mathrm{~kg} / \mathrm{ha})$ and total $(97.83$ and $90.43 \mathrm{~kg} / \mathrm{ha}$ ) of $\mathrm{Bt}$ cotton as compared to irrigation regimes of 1.0 ET and surface method (control). Increasing the nitrogen uptake by seed, straw and total of Bt cotton with increasing of nitrogen levels from $50 \%$ RDN\&K to $100 \%$ RDN\&K. The significantly higher nitrogen uptake by seed $(35.83 \mathrm{~kg} / \mathrm{ha})$, straw $(61.00 \mathrm{~kg} / \mathrm{ha})$ and total $(96.53 \mathrm{~kg} / \mathrm{ha})$ of $\mathrm{Bt}$ cotton was recorded under application of $100 \%$ RDN\&K over application of $75 \%$ and $50 \%$ RDN \& K nitrogen uptake by seed (27.83 and $23.48 \mathrm{~kg} / \mathrm{ha}$ ), straw (50.77 and $47.58 \mathrm{~kg} / \mathrm{ha})$ and total (78.60 and 61.06 $\mathrm{kg} / \mathrm{ha}$ ), respectively. These results are in accordance with the findings of Bhalearo et al., (2008) and Salikanop et al., (2010).

\section{Nitrogen use efficiency}

The pooled data shows that (Table 4) the significantly increase nitrogen use efficiency of $\mathrm{Bt}$ cotton under various irrigation regimes. Application of irrigation at 0.6 ET and $0.8 \mathrm{ET}$ were found at par with each other in terms of nitrogen use efficiency (23.33 and $22.12 \mathrm{~kg}$ $\mathrm{kg}^{-1} \mathrm{~N}$ ) of Bt cotton as compared to irrigation regimes of $1.0 \mathrm{ET}$ and surface method (control). Increasing the nitrogen use efficiency of $\mathrm{Bt}$ cotton with increasing of nitrogen levels from $50 \%$ RDN\&K to $100 \%$ RDN\&K. The significantly higher nitrogen use efficiency $\left(21.52 \mathrm{~kg} \mathrm{~kg}^{-1} \mathrm{~N}\right)$ of Bt cotton was observed under application of $100 \%$ RDN\&K over application of $75 \%$ and $50 \%$ RDN \& $\mathrm{K}$ (20.56 and $19.37 \mathrm{~kg} \mathrm{~kg}^{-1} \mathrm{~N}$ ), respectively. Optimal $\mathrm{N}$ fertilizer rate was applied, crop NUE averaged $12.5 \pm 0.2 \mathrm{~kg} / \mathrm{lint}$ $\mathrm{kg}$ /crop $\mathrm{N}$ uptake. Crop $\mathrm{N}$ uptake averaged $247 \mathrm{~kg} \mathrm{~N} \mathrm{ha}^{-1}$ for lint yield $2.27 \mathrm{t} \mathrm{ha}^{-1}$ and crop NUE $10 \mathrm{~kg}$ lint $\mathrm{kg}^{-1}$ crop under flood irrigation of Australia (Rochester, 2011). Pakistan drip irrigation system registered 22\% higher lint yields with plant spacing $10 \mathrm{~cm}$ over furrow irrigation and plant spacing $30 \mathrm{~cm}$ with $7.9 \mathrm{~kg} \mathrm{ha}^{-1} \mathrm{~mm}^{-1}$ WUE and water saving of 53\% (Sadashivappa and Qaim, 2009).

\section{Water use efficiency}

The pooled data of two years shows that (Table 5) the significantly increase water use efficiency of $\mathrm{Bt}$ cotton under various irrigation regimes. Application of irrigation at 0.6 ET was recorded higher water use efficiency $(26.30 \mathrm{~kg} \mathrm{ha} / \mathrm{cm})$ as compared to irrigation regimes of 1.0 ET and surface method (control). However, it was found at par with irrigation regime of $0.8 \mathrm{ET}$ water use efficiency $(25.19 \mathrm{~kg} \mathrm{ha} / \mathrm{cm})$. Increasing the water use efficiency of $\mathrm{Bt}$ cotton with increasing of nitrogen levels from $50 \%$ RDN\&K to $100 \%$ RDN\&K. The significantly higher water use efficiency $(27.35 \mathrm{~kg} \mathrm{ha} / \mathrm{cm})$ of $\mathrm{Bt}$ cotton was observed under application of $100 \%$ RDN\&K over application of $75 \%$ and $50 \%$ RDN \& $\mathrm{K}(22.12$ and $19.15 \mathrm{~kg}$ $\mathrm{ha} / \mathrm{cm})$, respectively. Additional profit of Rs. 14, 000/-ha ${ }^{-1}$ was shown by supplemental irrigation by early adopted Bt hybrid cotton farmers in Maharashtra 2004-06 (Subramaniam \& Matin, 2010).

\section{Economics}

It is evident from pooled data shows that (Table 5) the application of irrigation regime 0.6 ET was recorded higher net return (Rs.48598/- ha $^{-1}$ ) and B:C ratio (2.31) over irrigation regime of $1.0 \mathrm{ET}$ and surface method (control), but it was found at par with irrigation regime of $0.8 \mathrm{ET}$ net return (Rs.46458/- ha $^{-1}$ ) and B:C ratio (2.30). The application of $100 \%$ RDN\&K gave significantly higher net return (Rs. 50380/ha $^{-1}$ ) and B: C ratio (2.29) over $75 \%$ and $50 \%$ RDN\&K net return (Rs. 37538/- and 30680/$\left.\mathrm{ha}^{-1}\right)$ and $\mathrm{B}$ : $\mathrm{C}$ ratio (1.79 and 1.53), respectively in the pooled analysis. These results are also in accordance with Jadhao et al., 1993, who noticed higher benefit cost ratio with transplanted cotton. 
It could be concluded that, the irrigation regime of 0.6 ET and application of $100 \%$ RDN \& $\mathrm{K}$ gave significantly higher seed cotton yield, water use efficiency and monetary return.

\section{References}

Bhalerao, P.D., Gawande, P.R., Ghatol, P.U. and Patil, B.R. 2008. Performance of Bt. cotton hybrids for various spacing under rainfed condition. Agric. Sci. Digest., 28 (1): 54- 56.

Dhawan, B. D. 2002. Technological Change in Indian Irrigated Agriculture: A Study of Water Saving Methods, Commonwealth Publishers, New Delhi.

Dong, H., W. Li, W. Tang, and D. M. Zhang, 2004. Development of hybrid Bt cotton in China - a successful integration of transgenic technology and conventional techniques. Current Sci. 86, 778-782.

Indian National Committee on Irrigation and Drainage (INCID) 1994. Drip Irrigation in India, New Delhi.

Jadhao, J. K., A. M. Degaonkar, and W. N. Narkhede, 1993. Performance of hybrid cotton cultivars at different plant densities and nitrogen levels under rainfed conditions. Indian J. Agron. 38, $340-341$.

Narayanamoorthy, A. 2003. Averting Water Crisis by Drip Method of Irrigation A Study of Two Water-Intensive Crops.
Indian J. Agricultural Economics 58 (3) pp. 427-437.

Narayanamoorthy, A. 2004. Drip Irrigation in India Can it Solve Water Scarcity, Water Policy, 6 (2) pp. 117-130.

Narayanamoorthy, A. 2005. Economics of Drip Irrigation in Sugarcane Cultivation Case Study of a Farmer from Tamil Nadu, Indian J. Agricultural Economics, 60 (2) pp. 235-248.

Rochester, I. J., 2011. Assessing internal crop nitrogen use efficiency in high-yielding irrigated cotton Nutrient Cycling. Agro ecosystems 90 (1): 147-156.

Sadashivappa, P. and M. Qaim., 2009. Bt Cotton in India: Development of benefits and the role of government seed price interventions. J. Agro Biotech Management and Economics, 12 (2): 3.

Salakinkop, S.R., Basavaneppa, M.A. and Chittapur, B.M. 2010. Economic viability of transplanting of Bt. cotton in irrigated conditions. J. Cotton Res. Dev., 24 (2): 196- 199.

Sivanappan, R.K. 1994. Prospects of Micro Irrigation in Indi, Irrigation and Drainage System, 8 (1) pp. 49-58.

Subramaniam, A. and Matin Q., 2010. The impact of Bt cotton on poor households in rural India, J. Development Studies, 46(2): 295-311.

\section{How to cite this article:}

Harphool Meena, K.C. Nagar, B.L. Kumhar and Bachchu Singh. 2018. Improving Use Efficiency of Inputs by Drip Irrigation in Bt Cotton. Int.J.Curr.Microbiol.App.Sci. 7(03): 36323638. doi: https://doi.org/10.20546/ijcmas.2018.703.419 